ations, of which the Commission for the Utilization of Atomic Energy is only one, which are autonomous on a day-to-day basis and which can be influenced from outside only occasionally, at a Party Congress, for example. This is why public administration is so tolerant of its own mistakes, and why even the most energetic new brooms cannot expect to have much influence quickly. This system, the source of the muddle and bureaucracy that shackles the Soviet Union, is ironically the instrument of the dictatorship of the proletariat. The means of production, from agriculture to atomic energy, are centrally owned and operated, supposedly on behalf of the proletariat, but by organizations that scem to have scant regard for people's interests. There is nothing new in this arrangement. The central organizations, inflexible since Lenin's time, are in many ways but extrapolations of the czarist bureaucracies. Mr Gorbachev's wish that the system would become more open will not be met until these quasi-autonomous inadequately accountable organizations are cut down to size. The obvious failures of the system in the past two weeks should give him an excuse to tackle its weaknesses, from which many good things may flow, a greater freedom for Sovict science in particular.

The often-prurient interest by the West in events at Chernobyl stems from the sense that what happened there may strike deeply at the way in which Soviet life is organized. The comparison with the disaster to the US shuttle in January is bound to spring to mind. That was as big a blow to national pride as anything that has happened in the Soviet Union; ironically, as it turns out, there are now complaints in the United States (by the chairman of the investigating commission in secret testimony to the US Congress) of a cover-up. There may be, most probably is, a lot wrong with US society, yet nobody has yet suggested that there is no way forward except by radical change. Mr Gorbachev's Union of Soviet Socialist Republics is not so lucky.

\section{Life without Joseph}

\section{The British government is to be modestly reshuffled, in which process lie opportunities.}

SIR Keith Joseph, for long one of the most controversial members of the British government, will no doubt be astonished by the way in which his public reputation is changing. Sir Keith let it be known some weeks ago that he would not be seeking reelection to the House of Commons at the next general election, which must be held during the next two years, whereupon the government let it be known that he would probably vacate his post as Secretary of State for Education and Science before the end of the present Parliament. That is a curious happening in itself; there is no obvious reason why a minister who will not be returning after the election should not, in the meantime, soldier on. which has led to the obvious speculation that Sir Keith's colleagues have come to share at least the mildest version of the common criticism of him, that he is full of good ideas at whose execution he is inept

Now, after the spectacular loss of a by-election last week and a poor showing in the local elections, the word is getting about that Sir Keith's departure from his post (but not necessarily from the government) will be sooner rather than later, not this week (which would seem over-hasty) nor even next (which would still seem a little soon), but perhaps the week after that. At the same time, there are suggestions that the British government will use the occasion for a wider shuffling of responsibilities. The remarkable consequence, for Sir Keith, is that the nostalgia that appears to accompany the departure of politicians from high office, impelling their loudest critics to declare that they were statesmen after all, has engulfed Sir Keith even before he has cleared his desk. After months of bruising argument with teachers in British schools, for example, there are now many educationalists who will acknowledge that he has been right to ask for mechanisms for improving the quality of teaching. Do
Sir Keith's constituents fear losing the man they love to hate?

Part of the British government's calculation seems to be that education is not the tediously boring matter it has seemed for the past several years, but instead an issue by means of which electoral unpopularity might be exorcized. The calculation is surely correct; great credit would certainly accrue to a government that was able to offer schooling of high quality to the whole of the population, and to provide higher education on a scale and of a character that would ensure rising or even merely continuing prosperity. But the goal may not be as easily attainable as the optimists among the government's strategists suppose. School systems and universities are sociologically complicated institutions which cannot be changed, or made to grow, at the snap of a politician's fingers (as the attempts at contraction over the past few years have shown). At the school level, hopes for a better system may in the present circumstances and perhaps permanently be frustrated by the difficulty of recruiting talented people who are able and willing to teach in schools. But the British government is also uncertain about its ambitions for the transformation of secondary education. For several years, in parallel with the general decline of morale of secondary school staff, it has been encouraging a series of experiments in vocational education under the aegis of the Department of Employment; now there is talk of putting the traditional and new initiatives together in a single ministry (which is a sensible idea). But the government would be mistaken if it thought that such a decision would magically bring about the general improvement that it rightly seeks. The best it can hope for quickly is that there might be a prospectus for improvement so persuasive, and so generously backed with promises of funds, that electors would suspend what otherwise is likely to be a harsh judgement.

In higher education, there is a different set of problems to be tackled. One sensible and simple step would be to give up the pretence that the demand for higher education is bound to fall, so that the provision of higher education must be forced to contract. Why not just leave the imponderable question to the market, avoiding in the process the contumely that must fall on governments that actively close institutions? Another issue is that of research, which is anomalously administered by Sir Keith's huge ministry, largely preoccupied with schools (and teachers' pay). If there is now to be a reorganization, why not take the opportunity to put civil research somewhere else, perhaps (as the House of Lords argued five years ago) with a parttime minister as its titular head? Moreover, the present is a splendid time for making such a change, for there is likely to be at least one under-employed member of the reorganized cabinet, Sir Keith Joseph himself, who has at least learned enough in the past few years of the ambitions of the research enterprise to have become a sympathizer if not a staunch defender.

Nobody can tell whether the government will have the stomach or the inclination for this sensible decision. For several decades, it has been plain that Britain, now almost proud of the way in which other people trade on its bright ideas, would be a more prosperous place if better use were made of science. From time to time (most recently, in the latest report of the government's favourite advisory committee, the Advisory Committee for Applied Research and Development just two weeks ago) people dare to say this publicly. Yet nothing happens, or nothing very much. Part of the trouble, when a government's calculation of electoral advantage has been foreshortened by political events, is that research is not numerically a substantial constituency. But even then, the sensible course might be well worth following. For even if research has become merely a financial burden, it remains a nuisance. Its practitioners are always writing to the newspapers complaining about their treatment. Would it not be a clever wheeze to get research off the government's back for the time being by giving the research community the rope with which to hang itself on the proposition that it knows as well as cabinet ministers how Britain might be made prosperous again? 